\title{
SEASONAL MORPHOLOGICAL VARIATIONS IN BIRD SCHISTOSOMES
}

\author{
BAYSSADE-DUFOUR C.* JOUET D.**, RUDOLFOVA J.***, HORÁK P.*** \& FERTÉ H.**
}

\section{Summary:}

The present work is a contribution to the systematics of Bilharziella and Dendritobilharzia. Wildfowl was killed in hunting seasons or found dead in Champagne-Ardenne region, France, and autopsied with focus on schistosomes. Seven Anas platyrhynchos (mallards), one Ardea cinerea (grey heron) and two Cygnus olor (mute swans) were parasitized by Bilharziella. One C. olor was parasitized by Dendritobilharzia. Depending on season and hosts, various morphological forms of Bilharziella suggesting several species were observed. The differences in male and female worms concerned the morphology of genital apparatus, the spination on suckers, the body size and proportions. However, the comparison of DNA sequences led to a conclusion that these forms belonged to one species, Bilharziella polonica (Kowalewski, 1895). The morphological features and the body sizes of our samples of Dendritobilharzia seemed to differ from the type species of D. pulverulenta (Braun, 1901). Nevertheless, molecular analysis confirmed identity. We hypothesize that the differences in Bilharziella and Dendritobilharzia might be linked to internal host factors (e.g. hormonal levels), and influenced by season, host, and worm age. The definition of the genera Bilharziella and

Dendritobilharzia was amended.

KEY WORDS : avian schistosome, Bilharziella polonica, Dendritobilharzia pulverulenta, morphology, systematics, molecular biology, France.
Résumé : VARIATIONS MORPHOLOGIQUES SAISONNIÈRES CHEZ LES SCHISTOSOMATIDAE AVIAIRES

Ce travail est une contribution à la systématique de Bilharziella et Dendritobilharzia (Trematoda, Schistosomatidae). Des oiseaux sauvages, tués en période de chasse ou trouvés morts en région de Champagne-Ardenne (France), ont été autopsiés pour rechercher la présence de schistosomes. Sept Anas platyrhynchos (colvert), un Ardea cinerea (héron cendré) et deux Cygnus olor (cygne tuberculé) ont été trouvés parasités par des Bilharziella. Un Cygnus olor est parasité par Dendritobilharzia. Selon la saison et la nature de l'hôte, plusieurs morphes de Bilharziella, suggérant plusieurs espèces, ont été observés. Les différences concernaient la morphologie de l'appareil génital, la spinulation des ventouses, la taille et les proportions du corps, chez les mâles comme chez les femelles. Or la comparaison des séquences d'ADN conduit à la conclusion que ces morphes appartiennent à une seule espèce, Bilharziella polonica (Kowalewski, 1895). Chez nos spécimens de Dendritobilharzia, des caractères morphologiques et la proportion de certains organes paraissent différents de ceux de D. pulverulenta (Braun, 1901), espèce type. Or, l'analyse moléculaire confirme l'identité de nos spécimens avec celle de l'espèce type. Nous formulons l'hypothèse que des différences dans Bilharziella et Dendritobilharzia pourraient être liées à des facteurs internes de l'hôte, taux hormonal notamment, et influencées par la saison, l'hôte et l'âge des vers. La définition des genres Bilharziella et Dendritobilharzia est amendée en fonction de ces observations.

MOTS CLÉS : bilharzie aviaire, Bilharziella polonica, Dendritobilharzia pulverulenta, morphologie, systématique, biologie moléculaire, France.

industry). Recent and numerous data were published for Trichobilharzia spp. in systematics and pathogenicity, in experimental and natural hosts: birds, mammals and humans. Conversely, data on Bilharziella and Dendritobilharzia remained less abundant. Occurrence of Bilharziella and/or Dendritobilharzia in Europe and all over the world were studied by some authors (Ejsmont, 1929; Szidat, 1929; Mehra, 1940; Bykhovskaya-Pavlovskaya \& Rizhikov, 1958; Palm, 1965; Khalifa, 1972 and 1976; Sulgovstowska, 1972; Martorelli, 1981; Kolárová et al., 1989 and 1997; Sepulveda et al., 1994).

Furcocercariae of Bilharziella were reported as a causal agent of swimmer's itch in Germany by Szidat (1930). Horák \& Kolárová (2000) also observed penetration of

some cercariae of B. polonica into the skin of tails and 61, rue Buffon,75231 Paris cedex 05, France.

** EA 3800, UFR de Pharmacie, 51, rue Cognacq-Jay, 51096 Reims, France.

**:* Charles University, Faculty of Science, Department of Parasitology, Vinicna 7, 12844 Prague 2, Czech Republic.

Correspondence : Hubert Ferté, EA 3800, UFR de Pharmacie, 51,rue Cognacq-Jay, 51096 Reims, France.

Tel.: 00 (33)326913597 - Fax: 00 (33)326913597.

E-mail: hubert.ferte@univ-reims.fr 
legs of mice, and the schistosomulae were able to survive and migrate to the lungs in this model. On the other hand, B. polonica role in swimmer's itch in Poland was not confirmed by Zbikowska (2003, 2004). No data were published on a possible pathology caused by Bilharziella dwelling in birds.

Furcocercariae of Dendritobilharzia were reported as a causal agent of swimmer's itch in Germany by Dönges (1965), and in New Zealand by Rind (1989). Pathological changes in hosts naturally infected by Dendritobilharzia were studied by Levine et al. (1956), Wilson et al. (1982) and Wojcinski et al. (1987).

Systematics of Bilharziella Looss, 1899 was reviewed by Yamaguti (1971) and Khalil (2002). Systematics of Dendritobilharzia Skrjabin and Zakharow, 1920 was studied by several authors (Mehra, 1940; Cheatum, 1941; Macko, 1959; Baugh, 1963; Ulmer \& Van de Vusse, 1970; Farley, 1971; Van de Vusse, 1979 and 1980; Leite et al., 1982; Rind, 1989; Sepulveda et al., 1994). The present work describes Bilharziella and Dendritobilharzia found in Champagne-Ardenne region, France. It focuses on systematics of Bilharziella and Dendritobilharzia using morphological and molecular investigations.

\section{MATERIAL AND METHODS}

$\mathrm{B}$ irds were either killed during the hunting period or found dead by members of ONCFS (Office National de la Chasse et de la Faune Sauvage) and network SAGIR. They originated mainly from Champagne region: Der-Chantecoq lake and surrounding ponds. Nine Anas platyrhynchos (mallards), four A. clypeata (shovelers), two A. strepera (gadwalls), four $A$. crecca (teals), one Aythya ferina (pochard), five C. olor (mute swans), two Ardea cinerea (grey herons), one Gallinula chloropus (moorhen) and three Larus ridibundus (black-head gulls) were examined. They were frozen before autopsy. The adult worms were found after the dissection of their intestinal, mesenteric and hepatic vessels and were fixed in alcohol or formaline, stained in chlorhydric carmine, dehydrated, mounted in Canada balsam and drawn with camera lucida.

Specimens of worms (Bilharziella and Dendritobilharzia) were analyzed for molecular biology. For each worm the anterior part of the body was cut for mounting, and morphological evaluation and determination. DNA extraction was done using the Qiamp DNA mini kit (Qiagen, Germany) following manufacturer's instructions. During the first step (tissue lysis), the worms were crushed one by one using a piston pellet (Treff, Switzerland), and the DNA was eluted in $50 \mu \mathrm{l}$ of the elution buffer provided by the manufacturer. PCR was performed in a $50 \mu \mathrm{l}$ volume using $5 \mu \mathrm{l}$ of extracted
DNA solution and 50 pmol of each of the primers C2'b (5'-GAAAAGTACTTTGRARAGAGA) and D2 (5'- TCCGTGTTTCAAGACGGG) for amplification of D2 domain of 285 rDNA. The PCR mix contained (final concentrations) $10 \mathrm{mM}$ Tris $\mathrm{HCl}, \mathrm{pH} 8.3,1.5 \mathrm{mM} \mathrm{MgCl}_{2}, \mathrm{KCl}$ $50 \mathrm{mM}$, Triton X $1000.01 \%, 200 \mu \mathrm{M}$ each dNTP, and $0.25 \mu \mathrm{l}$ (1.25 units) of Taq polymerase (Qiagen, Germany). Initial denaturation at $94^{\circ} \mathrm{C}$ for five min was followed by 40 cycles of denaturation at $94^{\circ} \mathrm{C}$ for $45 \mathrm{~s}$, annealing at $50^{\circ} \mathrm{C}$ for $45 \mathrm{~s}$ and extension at $72^{\circ} \mathrm{C}$ for two min with a final elongation time of $10 \mathrm{~min}$ at $72^{\circ} \mathrm{C}$. Amplicons were analysed by electrophoresis in $1.5 \%$ agarose gel containing ethidium bromide. PCR products were directly sequenced in both directions by Qiagen (Hilden, Germany) using the primers used for DNA amplification. Sequence alignment was performed using the MUST software package (Philippe, 1993). The sequences are deposited in Genbank (accession Nos. DQ813437 to DQ813443).

\section{RESULTS}

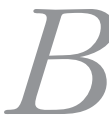

ilharziella was found in two C. olor (out of five examined) and $A$. cinerea found dead in autumn in Outines. Bilharziella was also found in seven A. platyrhynchos (out of nine examined), three coming from Vanault-les-Dames and killed by hunting in September and October, and four from Larzicourt, killed at the end of June (Table I). Dendritobilharzia was only found in one C. olor parasitized also by Bilharziella. Previously, Bilharziella and Dendritobilharzia were rarely mentioned in findings from wildfowl in Western Europe.

\section{BILHARZIELLA (Figs 1, 2)}

Specimens have been found in mesenteric or hepatic vessels. Their digestive and genital apparatuses allowed identification as Bilharziella sp. Besides the characters common to Bilharziella, the worms displayed an excretory system visible only at the end of the body. The genital apparatus in males showed a long gynaecophoric canal extending from the level of oral sucker to the hindbody. It appeared as a tubercled strip or drainpipe, opened or closed. Size and morphological features allowed to distinguish four morphological types: one from C. olor (71 TO), one from A. cinerea ( $72 \mathrm{TO}$, 76 TO 1,2) and two in A.platyrhynchos: one observed in June (64 TO, $65 \mathrm{TO}, 77 \mathrm{TO}, 78 \mathrm{TO})$ and the others in September-October (63 TO, 66 TO, 73 TO, 74 TO). Only one male was observed in each $C$. olor which died in November. One of the worms put in a drop of water measured $5,830 \mu \mathrm{m}$ in length, the diameters of oral sucker and acetabulum were respectively $150 \mu \mathrm{m}$ and $190 \mu \mathrm{m}$, the distance between the two suckers was 


\begin{tabular}{|c|c|c|c|c|c|}
\hline Parasite & Host & Location in bird & $\begin{array}{c}\text { Registration } \\
\text { number } \\
\text { (Paris) }\end{array}$ & $\begin{array}{c}\text { Geographical } \\
\text { data }\end{array}$ & $\begin{array}{c}\text { Death } \\
\text { of the bird }\end{array}$ \\
\hline \multirow[t]{2}{*}{$\begin{array}{l}\text { Bilharziella polonica } \\
\text { large morph without spine }\end{array}$} & $\begin{array}{l}\text { Cygnus olor } \\
\text { (DER 1) }\end{array}$ & Mesenteric, male & 71 TO 1 & \multirow{2}{*}{$\begin{array}{l}\text { Outines } \\
\text { Landres pond } \\
4^{\circ} 41^{\prime} 14^{\prime \prime} \mathrm{E} \\
48^{\circ} 34^{\prime} 33^{\prime \prime} \mathrm{N}\end{array}$} & November, 25 \\
\hline & $\begin{array}{l}\text { Cygnus olor } \\
\text { (DER 3) }\end{array}$ & Mesenteric, male & 71 TO 2 & & $i d$ \\
\hline \multirow[t]{3}{*}{$\begin{array}{l}\text { Bilharziella polonica } \\
\text { large morph without spine }\end{array}$} & $\begin{array}{l}\text { Ardea cinerea } \\
\text { (ARD 1) }\end{array}$ & Mesenteric, male & 72 TO 1 & \multirow[t]{3}{*}{ Outines } & \multirow[t]{3}{*}{ Autumn } \\
\hline & & Mesenteric, female & 76 TO 1 & & \\
\hline & & Mesenteric, female & 76 TO 2 & & \\
\hline \multirow[t]{4}{*}{$\begin{array}{l}\text { Bilharziella polonica } \\
\text { medium morph without spine }\end{array}$} & $\begin{array}{l}\text { Anas platyrhynchos } \\
\text { (KAL 5) }\end{array}$ & Mesenteric, male & 63 TO 1 & \multirow{4}{*}{$\begin{array}{l}\text { Vanault-Les-Dames } \\
\text { Neuf pond } \\
4^{\circ} 47^{\prime} 12^{\prime \prime} \mathrm{E} \\
48^{\circ} 50^{\prime} 31^{\prime \prime} \mathrm{N} \\
\text { id. }\end{array}$} & September, 30 \\
\hline & & Mesenteric, female & $74 \mathrm{TO} 2$ & & \\
\hline & $\begin{array}{l}\text { Anas platyrbynchos } \\
\text { (KAL 9) }\end{array}$ & Mesenteric, female & 66 TO 1 & & October, 6 \\
\hline & & Mesenteric, male & 73 TO 1 & & \\
\hline \multirow[t]{4}{*}{$\begin{array}{l}\text { Bilharziella polonica } \\
\text { medium morph with spines }\end{array}$} & $\begin{array}{l}\text { Anas platyrbynchos } \\
\text { (FRA 1) }\end{array}$ & Hepatic/mesenteric male & 64 TO 1 & \multirow{4}{*}{$\begin{array}{l}\text { Larzicourt } \\
\text { Der-Chantecoq lake } \\
4^{\circ} 43^{\prime} 04^{\prime \prime} \mathrm{E} \\
48^{\circ} 34^{\prime} 33^{\prime \prime} \mathrm{N}\end{array}$} & June, 29 \\
\hline & & Hepatic/mesenteric male & 77 TO 1 & & \\
\hline & & Hepatic/mesenteric male & 78 TO 1 & & \\
\hline & $\begin{array}{l}\text { Anas platyrhynchos } \\
\text { (FRA 2) }\end{array}$ & Hepatic/mesenteric female & 65 TO 1 & & June, 29 \\
\hline Dendritobilharzia pulverulenta & $\begin{array}{l}\text { Cygnus olor } \\
\text { (DER 1) }\end{array}$ & Hepatic males and females & 55 TO 1,10 & $\begin{array}{l}\text { Outines } \\
\text { Landres pond } \\
4^{\circ} 41^{\prime} 14^{\prime \prime} \mathrm{E} \\
48^{\circ} 34^{\prime} 33^{\prime \prime} \mathrm{N}\end{array}$ & November, 25 \\
\hline
\end{tabular}

Table I. - Origin of samples.

1,310 $\mu \mathrm{m}$ (Fig. 1J). One male and two females occurred in $A$. cinerea found dead in autumn. The male was not measured, because it was fragmented (Fig. 1E). The two females put in a drop of water had a respective length of 2,149 and 2,161 $\mu \mathrm{m}$. The diameter of their oral sucker was $52 \mu \mathrm{m}$, acetabulum $73 \mu \mathrm{m}$ and the distance between their two suckers $401 \mu \mathrm{m}$ (Fig. 1F). In the worms recovered from $A$. cinerea and from $C$. olor, there were no spines on the suckers and males showed a reduced seminal vesicle. In $A$. platyrhynchos hunted in Vanault-les-Dames in autumn (September-October), nine males and three females of Bilharziella were studied. Five males and one female were examined from A. platyrhynchos from Larzicourt killed in summer (June). All the worms were measured after fixation and staining. Always males were longer and wider than females. The lengths in samples from ponds of Vanault-lesDames were: 2,977 $\pm 366 \mu \mathrm{m}$ (range 2,628-3,878) for nine males and 1,664 $\pm 112 \mu \mathrm{m}(1,556-1,780)$ for three females. Males and female from Larzicourt measured in lengths 3,165 $\pm 481 \mu \mathrm{m}(2,410-3,707)$ and $1,811 \mu \mathrm{m}$, respectively. All the samples appeared to be adult. Specimens of Bilharziella from A. platyrhynchos killed in Vanault-les-Dames in autumn were named A group, and those from $A$. platyrhynchos killed in Larzicourt in summer $\mathrm{S}$ group.
In A group, the bodies of male and female Bilharziella were relaxed. The males (Fig. 1A) showed a reduced linear seminal vesicle, with prostatic glands similar to the homologous organs (Fig. 1B) in the already synonymized species Chinhuta indica Lal, 1937. The females had a sinuous S-shaped ovary, a uterus with one (or none) poorly developed egg devoid of long spine, and a vitelline mass in midbody and hindbody (Fig. 1C, D). The hindbody was slender. The oral sucker and the acetabulum of males and females were smooth, devoid of spines (Fig. 1H, I). In $\mathrm{S}$ group, the males were frequently constricted (Fig. 2A, D). They displayed a long spiraled seminal vesicle (Fig. 2G) more similar to the vesicle of Bilharziella lali Baugh, 1963 than that reported in B. polonica (Kowalewski, 1895). The female had a globular ovary and vitelline follicles of equal dimensions filling the midbody and hindbody (Fig. 2K). The uterus and the hindbody were widened. The oral sucker and the acetabulum of males and female were spiny (Fig. 2B, C, E, F, H, I).

Molecular analysis performed with specimens from C. olor, A. cinerea and A. platyrbynchos (A and S groups) showed that all isolates belonged to Bilharziella polonica; the sequences of samples coming from the above mentioned birds were identical. They were homologous in $100 \%$ with the two sequences depo- 

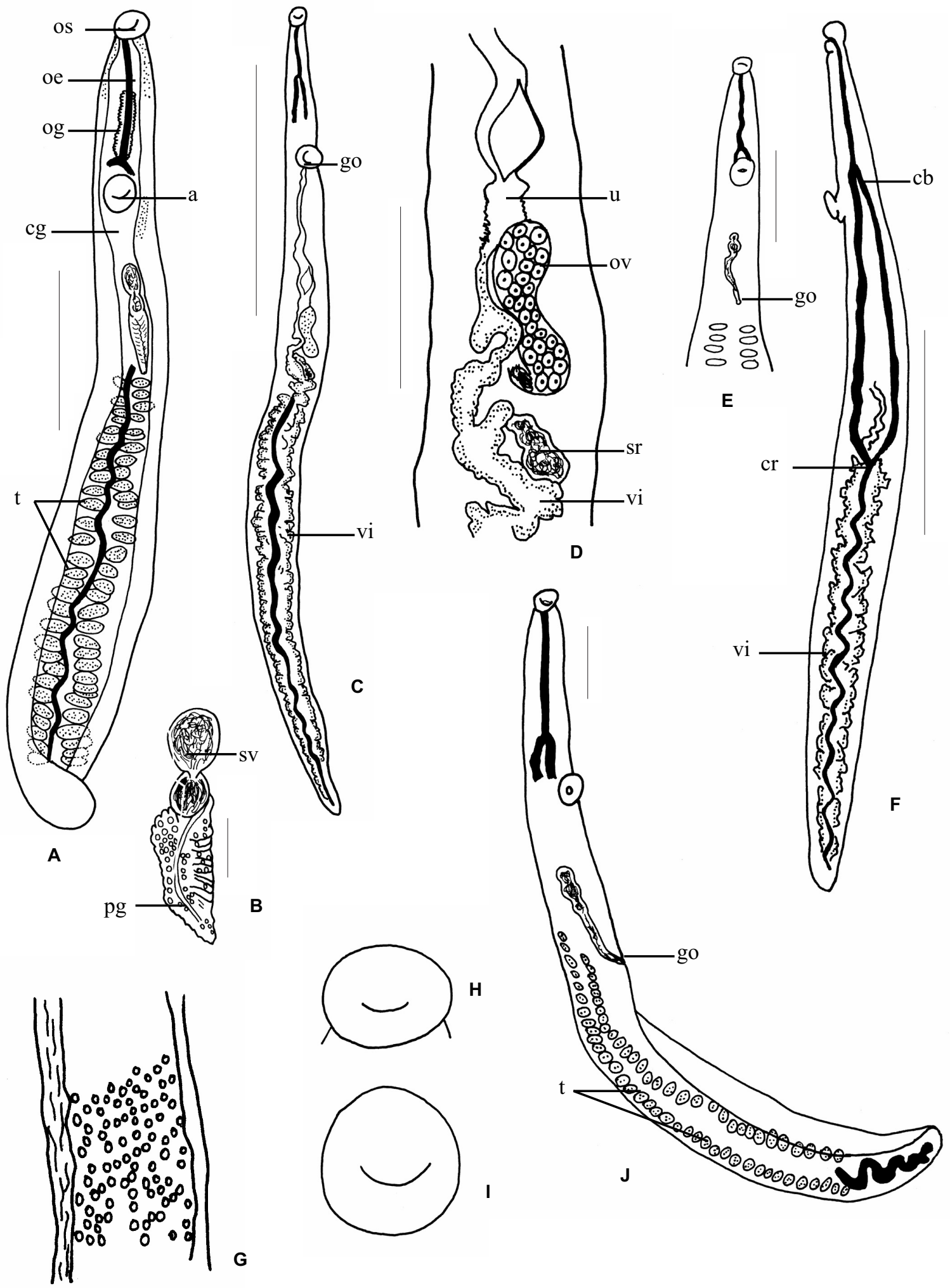

Fig. 1. - Bilharziella polonica autumn morph (A-D, G-I: Anas platyrhynchos; E, F: Ardea cinerea; J: C. olor) (male: A, B, E, G, J; female: C, D, F, H, I).

A: ventral view (63 TO). B: genital apparatus. C: ventral view (66 TO). D: genital apparatus. E: hinbody (Ardea cinerea). F: lateral view (Ardea cinerea). G: details of canalis gynaecophorus $\left(72 \mathrm{TO}_{1}\right)$. H: oral sucker $\left(76 \mathrm{TO}_{2}\right)$. I: acetabulum. J: ventro-lateral view (Cygnus olor) (71 $\left.\mathrm{TO}_{1}\right)$.

Abbreviations. - a: acetabulum, cg: canalis gynaecophorus, cb: caeca bifurcation, cr: caecal reunion, go: genital opening, i: intestine, oe: oesophagus, og: oesophageal glands, os: oral sucker, ov: ovary, pg: prostatic gland, sr: seminal receptacle, sv: seminal vesicles, t: testes, u: uterus, vi: vitelline folicles (scale bars: A, C, E, F, J = 500 $\mu \mathrm{m} ; \mathrm{B}, \mathrm{D}=100 \mu \mathrm{m}$ ). 

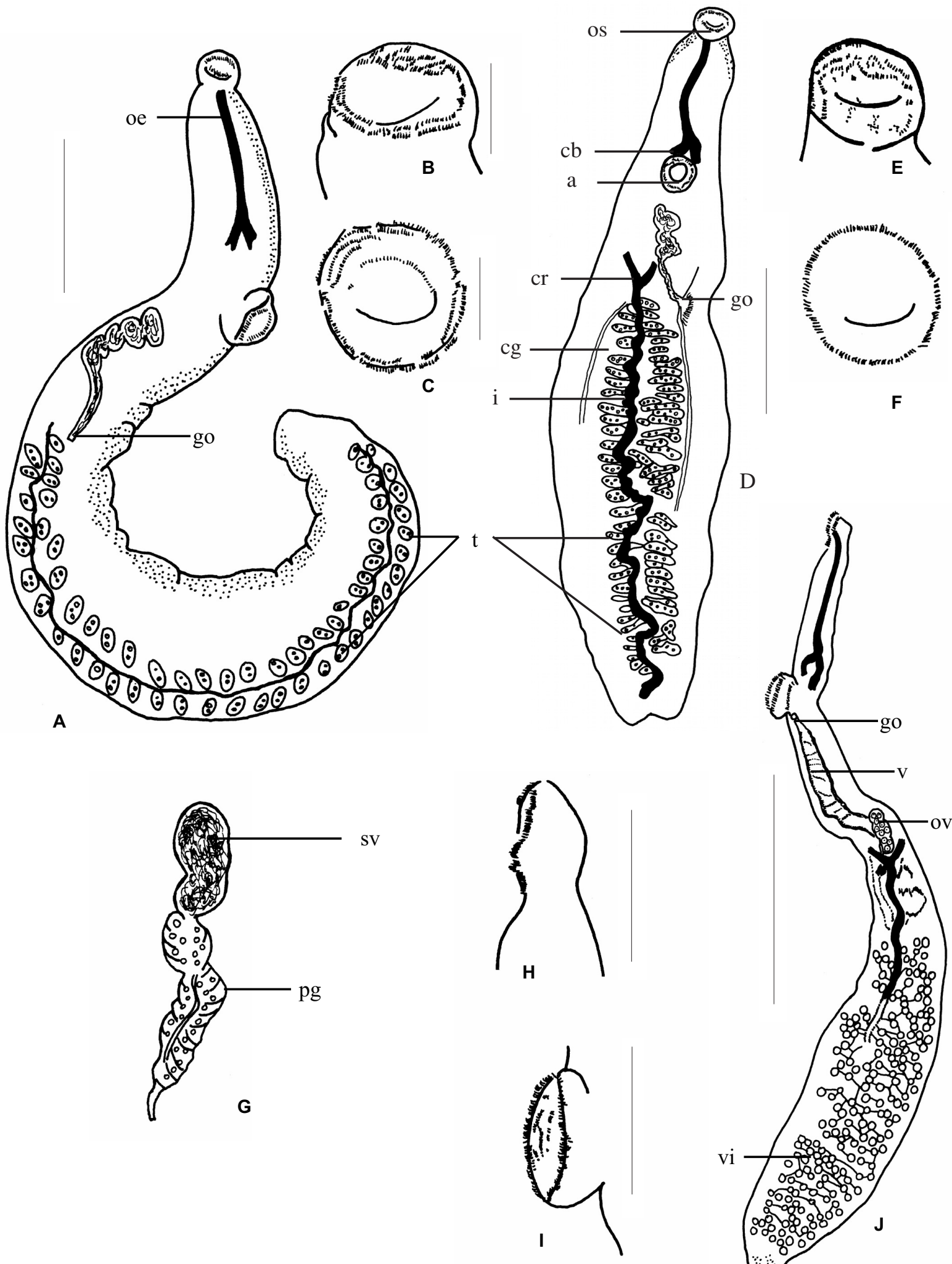
sited in Genbank, one obtained from a sample isolated from Anas platyrhynchos sacrificed in Ukraine, access number AY 157240 (Snyder \& Loker, 2000) and the second one obtained from ocellate furcocercariae of Bilharziella emitted by Planorbis planorbis from the Czech Republic, access number AF 167088 (Lockyer et al., 2003).

\section{DENDRITOBILHARZIA (Fig. 3)}

Three females and three males out of ten adult worms, found in hepatic vessels in one C. olor (55 TO 1-6) and determined as Dendritobilharzia sp. were morphologically studied. The length and the width of the fixed specimens were $12,740 \pm 770 \times 1,450 \pm 130 \mu \mathrm{m}$, without a significant difference between the males and the females. In both sexes oral and ventral suckers were not present (Fig. 3A, D). The digestive tract begun by oral opening situated subterminally. Oesophagus in its distal part was surrounded by oesophageal glands (Fig. 3B, E). Caecal bifurcation was at the level of cirrus pouch in males, or ovary, Mehlis' gland and uterus in females. Two short caeca reunited into a long dendritic intestine running zigzag to the posterior end of the body. In females, numerous eggs were present in the uterus at the morula stage; they were ovoid except for one with a terminal spine (Fig. 3F). In males the genital apparatus appeared to lack the gynecophoric canal. However, the edges of worms bore scattered spines, creases and bulges, participating probably in worm coupling. Cirrus pouch, seminal vesicle and prostatic cells were situated in the forebody. Ejaculatory duct opened in large genital bulb (Fig. 3C). A high number of testes organized in four lines were localized near the dendritic intestine. The sequence of the D2 domain of the $28 \mathrm{~S}$ rDNA is $100 \%$ homologous with that of Dendritobilharzia pulverulenta isolated from Gallus gallus (AF167090 or AY157241)

\section{DISCUSSION}

$A$ species is considered as separate among closely related ones on the basis of constant differences in morphology of adult worms, specificity for first molluscan hosts, shape and size of eggs harbouring a miracidium and typical sequences in genome. Usually ITS (Internal Transcribed Spacer) sequences served as molecular markers for species identification of Trichobilharzia (Dvorak et al., 2002). In our work, the D2 domain of 28 rDNA has been used as a relevant informative marker which is supported by use of D2 for discrimination of four species of human schistosomes (Littlewood \& Johnston, 1995). Males and females of Bilharziella from C. olor, A. cinerea and A. platyrhynchos showed morphological differences, but molecular analysis proved they belong to one species: $B$. polonica. In addition males and females of Dendritobilharzia from $C$. olor seemed morphologically different from the type species, but molecular data confirmed they belong to one species: $D$. pulverulenta.

\section{BILHARZIELLA}

Khalifa (1972) obtained cercariae of B. polonica from Planorbis planorbis, Bathyomphalus contortus and Planorbarius corneus, never from Anisus vortex, Lymnaeidae and Physidae. He succeeded an experimental infection of young $A$. platyrhynchos with furcocercariae emitted by naturally infected Planorbidae. The ducks were sacrificed at different periods after exposure. With respect to their age, the worms presented certain variability. However, despite their differences in morphology, Farley (1971) suggested a synonymy between B. lali Baugh, 1963 and B. polonica (Kowalewski, 1895).

In the present study the two observed forms (A and S) of Bilharziella from A. platyrhynchos differed in several morphological characters according to the season (e.g. presence or absence of spines on the two suckers, morphology of genital apparatus). In all the birds killed in autumn male and female genital apparatuses were always reduced, independently of the size of the worms. It was impossible to characterize several structures due to immaturity of some worms. Species identification of both forms (A and S) as B. polonica was proved by molecular tools.

A seasonal influence of the host on blood parasites has been reported in amphibians by Stunkard (1959) and Combes (1967). Stunkard pointed out that Polystoma (a monogenean parasite) was strictly haematophagous and could ingest the hormone-containing blood of its hosts. Combes observed correlation between the sexual cycle of Polystoma and the amphibian host. In adult birds of $A$. platyrhynchos, seasonal variation in the level of hormones present in the blood is also well known (Dorst, 1956). The level increases in spring and summer and decreases in autumn and winter. The increase of hormones in the blood was linked with the lengthening of the days in spring and summer. The day light activated the process of seasonal growing of gonads, inducing nuptial parades and nesting. Conversely, the shortening of days in autumn and winter stopped the process. The hormones of birds could influence the worm morphology and, based on the above examples, Bilharziella worms living in the blood of birds could monitor hormonal levels, controlling in this way onset and cessation of reproduction according to the season. In agreement with this hypothesis, we recorded influence of the season on the morphology of B.polonica. In addition, we can also speculate on e.g. influences of time of infection, worm natural ageing/maturation and size of bird host. 


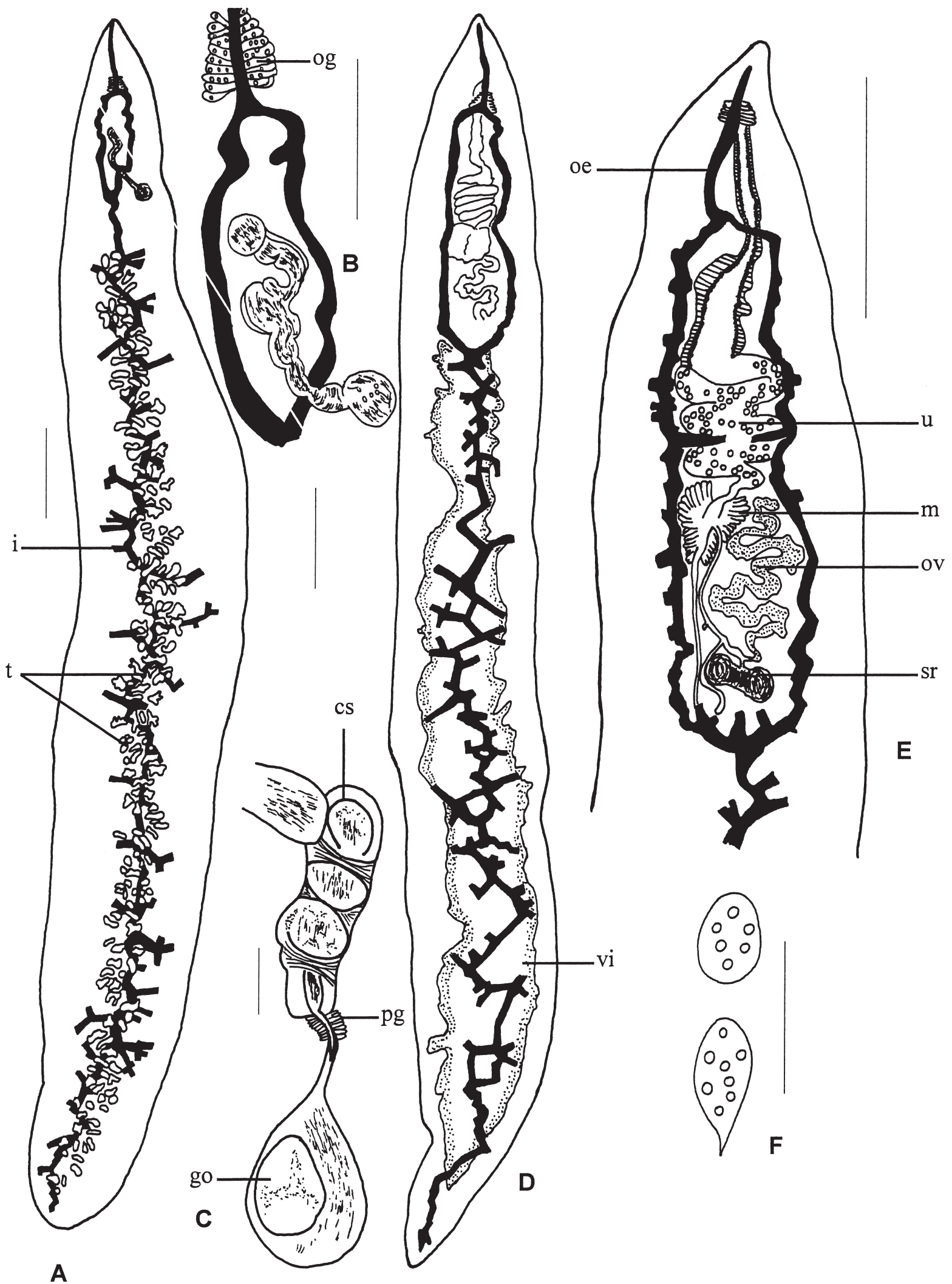

Fig. 3. - Dendritobilharzia pulverulenta (Cygnus olor) (male: A-B; female: D-F).

A: dorsal view $\left(55 \mathrm{TO}_{1}\right)$. B: genital apparatus, dorsal view $\left(55 \mathrm{TO}_{3}\right)$. C: genital apparatus, ventral view. D: ventral view $(55 \mathrm{TO} 4)$. apparatus $\left(55 \mathrm{TO}_{6}\right)$. F: eggs.

Abbreviations. - cs: cirrus sac, go: genital opening, i: intestine, m: Mehlis' gland, oe: oesophagus, og: oesophageal glands, ov: ovary, pg: prostatic gland, sr: seminal receptacle, t: testes, u: uterus, vi: vitelline folicles (scale bars: $\mathrm{A}, \mathrm{D}, \mathrm{E}=1 \mathrm{~mm} ; \mathrm{B}=500 \mu \mathrm{m} ; \mathrm{C}, \mathrm{F}=100 \mu \mathrm{m}$ ). 
The status of Bilharziella Looss, 1899 was discussed by several authors (Lal, 1937; Baugh, 1963; Yamaguti, 1971; Khalifa, 1972; Liu \& Bai, 1976; Farley, 1971; Khalil, 2002). Farley (1971) synonymized Chinbuta indica Lal 1937 and Bilharziella lali Baugh 1963 i.e. he synonymized the genera Chinhuta and Bilharziella. For both he admitted the absence of gynaecophoric canal. Yamaguti (1971) maintained validity of the two genera. He underlined the presence of gynaecophoric canal in Chinhuta. Khalil (2002) accepted the Farley's view. We also agree with synonymy of Bilharziella and Chinhuta, and the presence of a gynaecophoric canal in both morphs. This canal can be opened or folded over.

In the present work, the characters of the genus Bilharziella can be corrected as follows: Suckers are well developed, smooth or spiny, oral sucker is smaller than acetabulum. Caecal bifurcation is situated near acetabulum, at the level or in front of it. The common caecum is without lateral branches and runs zigzag. In males, gynecophoric canal is present, clearly obvious if closed or less apparent if opened. It is marked by two longitudinal bands: one smooth and the second one covered by tubercles extending from the inferior part of the oral sucker to the hindbody (Fig. 1G).

\section{DENDRITOBILHARZIA}

Van de Vusse (1979) noted locations of Dendritobilharzia in several arteries of birds (aorta, femoral and renal arteries, etc.) and admitted that these locations were different in surface ducks and diving ducks. The corresponding eggs were scattered in different tissues: intestine, liver, kidney of the bird hosts, and appeared to be non-developed. Our specimens of adult worms were found in hepatic vessels and no egg was found in the surrouding tissues. Morphology of our samples of males and females of Dendritobilharzia from C. olor seemed to be different from D. pulverulenta (Braun, 1901) described in Africa, and specimens found by Ulmer \& Van de Vusse (1970) in North America, and Rind (1989) in New Zealand. D. pulverulenta was reported also in Germany by Palm (1965), Poland by Sulgostowska (1972) and Khalifa (1972), the Czech Republic by Kolarova et al. (1989, 1997), Yakutiya by Bykhovskaja-Pavlovskaja \& Rizhikov (1958), Texas by Canaris et al. (1981) and India by Chauhan et al. (1973).

Body sizes of worms in our study were different from those mentioned by Macko (1959) and Van de Vusse (1980). Our female worms from C. olor morphologically resembled those of $D$. asiatica Mehra, 1940, with one spiny egg among numerous ovoid eggs. Males in our findings had a large genital bulb as $D$. anatinarum Cheatum, 1941; unfortunately, the male of D. asiatica was never described. Although Freitas \& Costa (1972) mentioned D. anatinarum in Brazil and Leite et al.
(1982) also recognized this species, Macko (1959) and Ulmer et al. (1970) consider it as a synonym of D. pulverulenta (Braun, 1901). Van de Vusse (1980) considered $D$. asiatica to be a species inquirenda, whereas Martorelli (1981) considered it as a valid species differing from $D$. pulverulenta and $D$. rionegrensis n. sp. Evaluating their specificities towards first intermediate hosts, it was difficult to confirm their synonymy. In Poland, Khalifa (1976) reported Anisus vortex and Planorbis planorbis as the first naturally infected hosts of D. pulverulenta, Leite et al. (1982) succeeded in the experimental infection of Biomphalaria straminea by miracidia identified as $D$. anatinarum. These miracidia came from eggs found in naturally infected Cairina moschata. The same authors failed in attempts to infect Aplexa rivalis, Biomphalaria glabrata and Lymnaea columella by miracidia of $D$. anatinarum. In New Zealand, Rind (1989) failed to establish D. pulverulenta infection in Potamopyrgus antipodarum, Gyraulus corinna and Lymnaea tomentosa.

Leite et al. (1982) and Rind (1989) observed that the maturation of $D$. anatinarum and $D$. pulverulenta eggs represents a long process. The intra-uterine eggs, as well as the deposited eggs are at morula stage. They grow and become mature outside the body of the female worms, in the intestinal mucosa of the bird host. The presence of numerous intra-uterine eggs, branching intestine and the absence of oral and acetabular suckers are the main differences between Dendritobilharzia and Bilharziella.

Our morphological and molecular data lead to a conclusion that $D$. pulverulenta is a species that could morphologically differ with respect to the physiological status of and location within the bird host. It means that it is extremely difficult to determine this species only by morphology of the adult worms. We think that the shape and size of genital bulb is not a species-specific feature and it could reflect physiological status of the male worm and its bird host.

An improved species diagnosis is proposed for Dendritobilharzia pulverulenta: Mouth devoid of oral sucker. Body devoid of acetabulum. Oesophageal glands near the caecal bifurcation. Caecal reunion in males at the level of the genital pore, in females at the level of ovary and seminal receptaculum. Common caecum long, zigzag, with lateral diverticula. In males, numerous testes lie posterior to caecal reunion on each side of common caecum; they occur in two, three or four rows reaching the posterior body end. The cirrus pouch contains a bipartite seminal vesicle, prostate and small or dilated genital bulb with a pore. The female genital system consists of a long and sinuous ovary, intercaecal seminal receptaculum lying behind ovary, Mehlis gland, sinuous uterus full of eggs, and metraterm ending in egg-laying pore near the oesophagus. Vitellaria spread from the level of ovary or seminal receptaculum until 
the hindbody. Excretory apparatus runs into a terminal pore. In male and female, crenated and brawny edges of the body with scattered spines and bulges are probably used during mating. The gynaecophoric canal is absent in males. The egg maturation continues after release into the intestine of bird host.

In the future it would be of interest to characterize the seasonality of the above mentioned morphological forms in experimental infections of birds. This might stimulate further work of taxonomists (intraspecific morphological variability) and physiologists (hormonal influence on parasite development). In addition, the naturally infected snails in the ponds and lakes where aquatic birds come from should be investigated in order to identify the intermediate hosts of B. polonica and $D$. pulverulenta. The intermediate host specificity should be verified experimentally by exposure of different planorbid snails to the above miracidia. The ability of cercariae to penetrate the skin of and migrate in vertebrates (birds, mammals) should also be tested.

\section{ACKNOWLEDGEMENTS}

T The authors thank Yves Maupoix, Mickael Combrexelle and the technical staff of ONCFS of lac du Der-Chantecoq, network SAGIR, Matthieu Kaltenbach and Grégoire Payen for their help in providing samples. Dr Jérôme Depaquit for his friendly contribution. Monique Boutry, Chantal Grimplet and Jimmy Cassone for their technical assistance. Financial support for this study was provided by ONCFS (Office National de la Chasse et de la Faune Sauvage). The research of J. Rudolfová and P. Horák was supported by: MSMT 0021620828 and GAUK 166/2005/B-BIO/PrF.

\section{REFERENCES}

BAugh S.C. Contributions to our knowledge of digenetic TrematodesVI. Zeitschrift fur. Parasitenkunde, 1963, 22, 303315.

Bykhovskaja-Pavloskaja I.E. \& Rijikov K.M. [Schistosomes (Schistosomatidae Looss, 1899) from anatids in Yakutiya.] Parazitologiceskij Sbornik Zoologiceskovo Instituta Akademii Nauch SSSR, 1958, 18, 283-294.

Canaris A.G., Mena A.C. \& Bristol J.R. Parasites of waterfowl from southwest Texas: III. The green-winged teal Anas crecca. Journal of Wildlife diseases, 1981, 17, 57-64.

Chauhan A.S., Srivastava C.B. \& Chauhan B.S. Studies on the trematoda fauna of India, 6. Digenea: Schistosomatidae. A monographic aid to the identification of Indian schistosomes. Journal of the Zoological Society of India, 1974, 25, 83-127.

Cheatum E.L. Dendritobilharzia anatinarum n. sp., a blood fluke from the mallard. Journal of Parasitology, 1941, 27, $165-170$
Combes C. Corrélations entre les cycles sexuels des Amphibiens Anoures et des Polystomatidae (Monogenea). Comptes Rendus de l'Académie des Sciences, Paris, Série D, 1967, 264, 1051-1052.

Dönges J. Schistosomatiden-Cercarien Süddeutschlands. Ein beitrag zur Kenntnis dermatitiserregender Trematodenlarven. Zeitschrift fur Tropenmedicin und Parasitologie, 1965, 16, 305-321.

Dorst J. Les migrations des oiseaux. Payot, Paris, 1956, 419 p.

Dvorák J., Vanacova S., Hampl V., Flegr J. \& Horák P. Comparison of European Trichobilharzia species based on ITS1 and ITS2 sequences. Parasitology, 2002, 124, 307-313.

EsjmonT L. Uber zwei Schistosomatidengattungen der Vögel. Bulletin de l'Académie Polonaise des Sciences et Lettres, Classe des Sciences Mathématiques Naturelles, Serie B : Sciences Naturelles, 1929, 2, 389-403.

FARLEY J. A Review of the Family Schistosomatidae: excluding the Genus Schistosoma from Mammals. Journal of Helminthology, 1971, 45, 289-320.

Freitas M.G. \& Costa H.M.A. Dendritobilharzia anatinarum Cheatum, 1941 em pato doéstico, no Brasil. Revista Brasileira Biologia, 1972, 32, 343-345.

HorÁk P. \& KolÁrová L. Survival of bird schistosomes in mammalian lungs. International Journal for Parasitology, 2000, 30, 65-68.

Khalifa R. Studies on Schistosomatidae Looss, 1899 (Trematoda) of aquatic bird of Poland. I. On the cycle of Bilharziella polonica Kowalesski, 1895, with a discussion of the subfamily Bilharziellinae Price, 1929. Acta Parasitologica Polonica, 1972, 20, 343-365.

Khalifa R. Studies on Schistosomatidae Looss, 1899 (Trematoda) of aquatic bird of Poland. III. Notes on the morphology and life cycle of Dendritobilharzia pulverulenta (Braun, 1901). Acta Parasitologica Polonica, 1976, 24, 1-9.

Kahlil L.F. Family Schistosomatidae Stiles and Hassal, 1898. In: Gibson A., Jones A. \& Bray R.A., Keys to the trematoda, Vol. I. Cab publishing, London, 2002, 419-432.

Kolárová L., Horák P. \& SitKo J. Cercarial dermatitis in focus: schistosomes in the Czech Republic. Helminthologia, 1997, 34, 127-139.

Kolárová L., Gottwaldová V., Cechová D. \& Sevcová M. The occurence of cercarial dermatitis in Central Bohemia. Zentrablatt und Hygiene, 1989, 189, 1-13.

KowALEWSKI L. Bilharziella polonica sp. nov. (Studya helmintologiczne 3). Rozprawy Wydzialu Matematyczno-Przyrodniczego Polskiej Akademii. Umiejetnosci Krakow, 1895, 31, $41-70$

LaL M.B. Studies on the Trematodes parasites of the birds. Part II. Morphology and Systematic position of some new Blood-Flukes of the family Schistosomidae. Proceedings of the Indian Academy of Sciences, 1937, 6, 274-283.

Leite A.C.R., Costa H.M.A., Costa J.O., Guimaraes M.P. \& Lima W.S. The life cycle of Dendritobilharzia anatinarum Cheatum, 1941 (Trematoda, Schistosomatidae). Memorias do Instituot Oswaldo Cruz, 1982, 77, 389-396.

Levine N.D., Clark D.T. \& Hanon L.E. Encephalitis in a swan due to Dendritobilharzia sp. (Trematoda; Schistosomatidae). Journal of Parasitology, 1956, 42, 496-500. 
LitTlewood D.T.J. \& Johnston D.A. Molecular phylogenetics of the four Schistosoma species groups determined with partial $28 \mathrm{~S}$ ribosomal RNA gene sequences. Parasitology, 1995, 111, 167-175.

LIU Z. \& BAI G. On bird schistosomes from Jilin Province: Jilinobilharzia crecci gen. nov., sp. nov. (Schistosomatidae: Bilharziellinae) with a discussion on the taxonomy of the subfamily of Bilharziinae. Acta Zoologica Sinica, 1976, 22, 385-392.

Lockyer A.E., Olson P.D., Ostergaard P., Rollinson D., JohnsTON D.A., ATtwood S.W., SOUThGate V.R., Horák P., SNyder S.D., Le T.H., Agatsuma T., McManus D.P., Carmichael A.C., NaEm S. \& LitTlewood D.T.J. The phylogeny of the Schistosomatidae based on three genes with emphasis on the interrelationships of Schistosoma Weinland, 1858. Parasitology, 2003, 126, 203-224.

Macko J.K. Zur Revision der Systematik der Trematode Dendritobilharzia anatinarum Cheatum, 1941. Helminthologia, 1959, 1, 133-137.

MarTORELli S.R. Dendritobilharzia rionegrensis sp. nov. (Digenea Schistosomatidae). Neotropica, 1981, 27, 171-177.

Mehra H.R. A new distome Enterohaematotrema n. g. and new blood fluke Hemiorchis bengalensis n.sp. belonging to the family Spirorchiidae Stunkard, and a new species of the genus Dendritobilharzia Skrjabin and Zakharow belonging to the family Schistosomatidae Poche, with remarks on the evolution of the blood flukes. Proceedings of the National Academy of Scicences of India, 1940, 10, 100-118.

PALM V. Ein Beitrag zur Helminthenfauna des Blesshuhns (Fulica atra L.) aus dem Raum von Postdam. Acta Parasitologica Polonica, 1965, 13, 425-444.

Philippe H. MUST a computer package of management utilities for sequences and trees. Nucleic Acids Resesarch, 1993, 21, 5264-5272

RIND S. Dendritobilharzia pulverulenta (Trematoda: Schistosomatidae) in New Zealand. New Zealand Journal of Zoology, 1989, 16, 215-220.

Sulgostowska T. Trematodes of the mute swan Cygnus olor from central and northern regions of Poland. Acta Parasitologica Polonica, 1972, 20, 473-481.

Sepulveda M.S., Spalding M.G., Kinsella J.M., BJork R.D. \& MaC LaUGHLin G.S. Helminths of the roseate spoonbill Ajaiai ajaja, in Southern Florida. Journal of Helminthological Society of Washington, 1994, 61, 179-189.

SNYDER S.D. \& LOKER E.S. Evolutionary relationships among the schistosomatidae (Platyhelminthes: Digenea) and an asian origin for Schistosoma. Journal of Parasitology, 2000, 86, 283-288.

STUNKARD H.W. Induced gametogenesis in a Monogenetic Trematode, Polystoma stellai Vigueras, 1955. Journal of Parasitology, 1959, 45, 389-394.

SzIDAT L. Die Parasiten des Hausgeflügels. 3 Bilharziella polonica Kow. ein im Blut Schmarotzender Trematode unserer Enten, seine Entwicklung und Ubertragung. Archiv für Geflügelkude, 1929, 3, 78-87.

SzIDAT L. Uber Hautinfektionen bei Bluttrematoden insbesondere bei Bilharziella polonica Kow. Archiv für Dermatologie und Syphilis, 1930, 160, 304-308.
Ulmer M.J. \& VAN DE Vusse F.J. Morphology of Dendritobilharzia pulverulenta (Braun, 1901) Skrjabin, 1924 (Trematoda: Schistosomatidae) with notes on secondary hermaphrodism in males. Journal of Parasitology, 1970, 56, 67-74

Van de Vusse F.J. Host-Parasite relations of Dendritobilharzia pulverulenta (Trematoda: Schistosomatidae) and anatids. Journal of Parasitology, 1979, 65, 894-897.

VAn DE Vusse F.J. A review of the genus Dendritobilharzia Skrjabin and Zakharow 1920 (Trematoda: Schistosomatidae). Journal of Parasitology, 1980, 66, 814-822.

Wilson R.B., New J.C. \& Scholtens R.G. Granulomatous encephalitis caused by schistosomiasis in swans. Jounal of America. Veterinar. Medical Association, 1982, 181, 1386-1387.

Wojcinski Z.W., Barker I.K., Hunter D.B. \& Lumsden H. An outbreak of schistosomiasis in Atlantic brant geese, Branta bernicola hrota. Journal of Wildlife Diseases, 1987, 23, 248255.

YAMAGuTI S. Synopsis of Digenetic Trematodes of Vertebrates: Keigaku Publishing Co, Tokyo, 1971, Vol. 1, 1074 p.; Vol. 2, $349 \mathrm{pl}$.

ZBIKOWsKA E. Is there a potential danger of "swimmer's itch" in Poland? Parasitology Research, 2003, 89, 59-62.

ZBIKOWsKA E. Infection of snails with bird schistosomes and the threat of swimmer's itch in selected Polish lakes. Parasitology Research, 2004, 92, 30-35.

Reçu le 14 février 2006 Accepté le 30 mai 2006 